\title{
Die lyf: fasette van die erotiese en seksuele in die Romeinse Ryk
}

P J J Botha

(Universiteit van Suid-Afrika)

\section{ABSTRACT}

\section{The body: aspects of eroticism and sexuality in the Roman empire}

An introduction to aspects of the erotic and sexuality in GrecoRoman antiquity requires some understanding of how people saw their bodies. What is considered erotic is related to the "ideal" body: sexuality manifests itself as culturally and historically determined. In this article relevant parts of the Greco-Roman cosmology is briefly discussed and concepts of the body analysed before an overview of love relations between women and men is presented. In the final section the shift in views about the body among the early Christians, is specified.

As 'n mens in die jaar 72 by die huis van Achilles - adres: Via di Nola, 10.5, Pompeije - ingestap het, sou mens soos te wagte, verskeie muurskilderye gesien het.

In die eetkamer van Achilles se huis is daar 'n treffende fresko wat Perseus en Andromeda uitbeeld. Dit is 'n baie bekende verhaal in die Romeinse wêreld: Andromeda word aan 'n rots vas geketting as 'n offer aan een van Neptunus se monsters weens haar ma, die koningin Kassiope se ydelheid. Perseus, die held wat kan vlieg, kom betyds daar aan, maak die ondier dood, bevry die meisie en trou met haar. Perseus is, in Romeinse oë, 'n ware held (en 'n seun van 'n god). Sy heldedaad en liefde vir Andromeda word orals in huise en paleise van die Romeinse Ryk uitgebeeld. Daar is 'n soortgelyke skildery in die huis van die priester Amandus in Via dell' Abbondanza, 1.7, drie blokke suid van Achilles se huis. En ook in die aristokratiese, uiters luukse villa Boscotrecase, vyf kilometer buite Pompeije.

In hierdie spesifieke skildery staan Perseus aan Andromeda se linkersy. Perseus is fors; sy arms is gespierd, sy skouers is breed en sy bolyf goed ontwikkel. Hy is besig om haar boeie los te maak. In die agtergrond roggel die sterwende ondier. Perseus se aanraking (sy regterhand aan haar linker elmboog) is teer. Andromeda hou die soom van haar kleed in haar regterhand, reg om van die rots af te 
klim - om dan teen Perseus te staan te kom. Die toneel beeld die moment uit waar Perseus, in Ovidius (die Romeinse digter) se woorde vir Andromeda sê: "Hierdie is nie die kettings wat jy verdien nie; beter is daardie wat minnaars saambind".

Ons, met oë wat ongewoon is aan destydse waardes, vermoed daar is erotiese spanning in die portret. Ons weet immers wat daar moet wees: die sluimerende fisiese energie wat tussen man en vrou broei. In die portret is Andromeda se houding inskiklik; haar kleed het van haar regterskouer afgegly en haar regterbors is kaal. Hy is heeltemal naak, soos wat 'n ware held destyds uitgebeeld word, fier en trots.

Maar dit is ook 'n vreemde uitbeelding. Ons wéét dit is die punt in die verhaal waar held en heldin op mekaar verlief raak. Maar hier kyk die man en meisie nie vir mekaar nie. Trouens dit lyk meer soos 'n formaliteit as 'n tere moment. Sy het geen glimlag nie; eerder 'n gedweë gesigsuitdrukking. Wat ook vir ons opvallend is, is dat Perseus se penis besonder klein - eintlik onnatuurlik klein geskilder is. Trouens, ál die helde in daardie wêreld word uitgebeeld as fris, gespierde mans; tog is hulle maar fyn besnaar.

Eintlik het die vervreemding vir ons al by die deur begin. Die deurklok wat melodieus met drie verskillende note klingel, is ' $n$ brons fallus. 'n Gevleuelde erekte fallus met 'n ereksie van sy eie én 'n stert in die vorm van 'n penis. Dít sou 'n ervaring vir ons gewees het, sou ons werklik deur tyd kon reis: waar presies trek mens so 'n klok?

In ander huise is daar lampies wat genitalieë uitbeeld. Stap ons in by die huis van die Vettii is daar 'n portret van Priapus wat 'n massiewe, letterlik ondraaglike penis reg in ons gesigte druk.

Loop ons in die dorp rond, of in ander stede van die Romeinse wêreld, is die uitstal van naaktheid (vir ons) baie opvallend. Vroeër of later besef ' $n$ mens: dit is 'n ander wêreld hierdie. Seks en die erotiese is 'n vanselfsprekende deel van ons lewens, 'n duidelike, ondubbelsinnige faset - of so dink ons totdat ons histories na ander mense van ander tye kyk.

Seks is baie meer as net penetrasie, en die erotiese is baie meer as net kaal lywe. Die erotiese word bepaal deur hoe ons ons liggame sien, en ons verwagtinge van wat ons nie moet sien nie. Dit is verweefd met ons waardes en voorkeure - en waardes en voorkeure 
is histories en kulturele verskynsels. "Eroties" is onder meer 'n refleksie van hoe mens die "ideale” liggaam beoordeel.

Ons almal ken die gevoel van 'n erotiese ervaring wat deur mens se lyf pols, maar die stimulus wat aanleiding daartoe gegee het, die betekenisse van daardie gevoel en die beoordeling van die handelinge wat daarop volg, is verbonde aan 'n spesifieke lyf in 'n kultureel bepaalde verhouding tot 'n ander lyf (of lywe). Seksualiteit is deel van alle mense van alle tye, maar die belewing en uitlewing van ons seksualiteit is historiese verskynsels.

Noodgedwonge, as ons die seksualiteit van die antieke mense wil verstaan, moet ons iets weet van hulle idees en opvattings oor die liggaam. (Met "antieke” bedoel ek in hierdie bespreking, die mense van die vroeë Romeinse ryk, die mense wat in die stede rondom die Middellandse See gewoon het gedurende die tydperk van die eerste eeu v.C. tot so aan die einde van die derde eeu n.C.).

In die volgende gedeelte bespreek ek kortliks iets van die kosmologie van destyds, daarna beskouinge oor die liggaam, dan 'n oorsig van liefdesverhoudings tussen mans en vroue. In die laaste gedeelte verduidelik ek kortliks die verskuiwing ten opsigte van liggaamlikheid wat plaasgevind het onder die vroeë Christene.

\section{MAG EN MAGTE}

Die mense van die Mediterreense wêreld tydens die Romeinse ryk was nie soos ons wat hulle seksualiteit betref nie. Die aksies en gebare wat uitgebeeld word en vermeld word deur antieke skrywers lyk en klink bekend, maar die betekenisse van daardie uitbeeldings is ver verwyderd van wat ons daaraan sou toedig. Hierdie is 'n wêreld vóór skaamte en skuld oor seks en erotiese dade.

Stel jou voor 'n wêreld waar intense vurige seks beskou is as iets om oor trots te wees, beskou is omdat 'n godheid jou liggaam vervul het - en allermins rede vir skuldgevoelens - 'n wêreld waar sommige handelinge wat ons as immoreel, selfs onwettig beskou, met genoegdoening gevier word.

Welkom in die wêreld van die eerste eeu.

Hierdie eerste gedeelte fokus op die kosmologie van die antieke mense, aspekte van die wêreldbeeld waarbinne Romeine van die eerste eeu hulle seksualiteit en erotiek beleef het. 
In die antieke wêreld was naaktheid duidelik deel van die openbare lewe. Gode, helde en keisers word naak uitgebeeld. Huise (ryk en arm) is vol van portrette met naakte mense. Breekware vertoon eksplisiete tonele van man-vrou en man-man liefdestonele. Elegante silwerware, bekers, borde en bakke, vertoon seks-tonele met indrukwekkende detail. Soldate drink uit erdebekers met afdrukke van kaal mense wat allerlei seksposisies illustreer (dalk het nie alles verander nie). Bad is vir Romeinse mense 'n openbare aktiwiteit. Mans is kaal in die gimnasium. Arbeiders dra die minimum klere.

Een van die vreemdste dinge vir óns oë is die oormaat falliese uitbeeldings. By die deur van baie huise staan hermes ('n herme is 'n falliese beeld wat dikwels die kop het van die god Hermes, die godheid wat oorgange en deurgange bewaak), meestal met 'n prominente, buitengewone groot ereksie. By sommige tempels in sekere dorpe staan reuse beelde van erekte penisse. Stap ons by die baddens in, is daar falliese simbole in die mosaïeke waaroor ons loop. By die tempels van die gode kry ons dankie-sê notas vasgemaak aan klein kleibeeldjies van genitalieë en vroueborste. Padaanwysers en grenspale is in die vorm van groot fallusse. Selfs op grafstene kry ons eksplisiete sekstonele.

Duidelik het hierdie uitbeeldings besondere simboliese waarde. Eintlik pas die woord "simbolies" in by ons wêreldbeeld want vir hulle, destyds was hierdie falliese figure, beelde en prente meer as net simbole; dit was knooppunte van die onsigbare wêreld met die sigbare, waar die onderliggende kragte van dit wat uitgebeeld word, kan kontak maak met die wêreld wat beleef word en waar energie gekanaliseer word.

Die beheptheid van die antieke mense met falliese simbole het te doen met hulle magiese wêreldbeeld. Die omvang en rol van magiese geloof en towerpraktyke in die daaglikse lewe van daardie mense kan nouliks oorskat word. Hierdie mense het nie net geglo in towerkrag, geeste, demone en magte nie - hierdie verskynsels was hulle werklikheid, alles saam deel van die eenheid van lewe.

In so 'n wêreldbeeld het alles 'n doel en alle gebeure het 'n aanstigter. Die logika is absoluut en vreesaanjaend. Dit is misleidend om te beweer dat moderne mense, mense met 'n wetenskaplike wêreldbeeld, 'n algehele vertroue in oorsaak en gevolg koester. Inteendeel, dit is ons wat die moontlikheid van toeval aanvaar. Vir 
diegene wat in 'n magiese wêreld lewe kan geen gebeurtenis "per ongeluk" of "toevallig" wees nie. Elke gebeurtenis is deel van 'n ketting van gebeure met een of ander persoon of "wese" of "mag" as die beslissende beginpunt. Mense met negatiewe gevoelens word deel van 'n destruktiewe ketting van gebeure en magte en so 'n persoon word die instrument van bose magte en afgunstige, onsigbare dog magtige wesens.

Een van die negatiewe magte vir antieke mense is die "bose oog”. Die bose oog is die verpersoonliking van jaloesie en nyd. Om nyd in die antieke wêreld te verstaan moet ons onthou dat mense toe gedink het alles wat bestaan is beperk; nie net geld en voedsel nie, maar ook roem en skoonheid en sukses. Iemand wat dus meer as 'n ander het, meer voorspoed of kos of bewondering, moes dit onregverdiglik verkry het en veroorsaak wanbalans in die wêreld. Dit is, terloops, hoekom antieke mense so ywerig was om te verklaar dat wat hulle het van God/die gode af kom, dat dit die gode/God se wil is en dat hulle, die bevoorregte mense, nie verantwoordelik daarvoor is nie en dus nie die objek van die bose oog kan wees nie.

In Galasiërs 3:1 vra Paulus: "Dwase Galasiërs, wie het julle met die bose oog bekyk?" Omdat dit so vreemde opmerking vir ons is, het die vertalers dit effe afgeplat met "wie het julle betower?" Paulus se betoog is dat sy opponente afgunstig is weens sy sukses en nou wil hulle die mense met donker magte beïnvloed. In die antieke wêreld kon die afgunstige persoon 'n ander siek maak of leed aandoen (partykeer selfs doodmaak) deur te fokus op daardie een wat in besit is van wat ookal beskou is as 'n ander se reg of eiendom.

Hoe het mense hulle beskerm teen die bose oog? Deur gebruik te maak van voorwerpe en afbeeldings van voorwerpe waardeur 'n positiewe mag gekanaliseer word. Daarom het baie mense in die antieke wêreld tattoeëermerke gedra, maar die meeste het van amulette en ringe gebruik gemaak. Die ideale teëmiddel vir die negatiewe mag was die positiewe krag/mag wat deur manlike lywe vloei en in die man se geslagsorgaan manifesteer.

Kom ons maak 'n draai by die huis van Menander (1.10, Pompeije) en besoek die huis se stel badkamers. Welaf mense het hulle eie private badsuites, nie soseer vir die gerief of die privaatheid nie, want meestal is daar in elk geval van die openbare baddens gebruik gemaak. Private badkamers was bedoel om die eienaar te laat kies saam met wie hy wil bad. Die huis van Menander is een van 
die mees eksklusiewe huise in die stad, hier kom die elite van die gemeenskap bymekaar.

Die badsuite het 'n kleinerige aantrekkamer, waaruit 'n smal gang na die caldarium (stoombad) lei. Op die vloer van die gang is 'n mosaïek wat die badhelper uitbeeld. Die figuur het 'n donker vel, dra badtoerusting, is skraps geklee met 'n klein lendedoekie en 'n massiewe geslagsorgaan hang uit.

Vir 'n Romein is bad uiters belangrik. Trouens, om 'n Romein te wees is om toegang tot baddens te hê. Tog is baddens ook gevaarlike plekke: 'n mens kan gly op die teels, verdrink, verbrand teen die vuurwarm vloer ('n Romeinse bad is van onder die vloer verhit) of selfs versmoor in 'n stoomkamer wat te warm is. Maar die grootste gevaar was dit wat ágter die fisiese bedreigings gelê het, fthonos of invidia. Hierdie woorde vertaal ons met afguns, maar eintlik wys dit op daardie destruktiewe kragte wat deur die bose oog uitgeskiet word. Met 'n bose oog kon 'n mens op wrokkerige kwaadwilligheid fokus want destyds het mense gedink jou oë is soos lampe. Die “lig”" waarmee 'n mens sien, stroom by jou oë uit. Dit wat die bose oog uitskiet, kan iemand tref en teëspoed, siekte en verliese veroorsaak. As die bose straal nie iemand tref nie, dwaal die negatiewe mag rond en versamel op donker plekke, of kruip agter hekke en deure weg.

Nou begryp ons die geweldige belang van voorwerpe, en uitbeeldings van voorwerpe wat beskerming bied teen sulke magte. Die meeste individue het apotropeons gedra: afbeeldings of voorstellinge wat krag ontleen aan die afgebeelde voorwerp en so die invloed van ander kragte kan afweer. En gegewe die derduisende voorbeelde wat ons gevind het, was die meerderheid hiervan falliese figuurtjies.

Wat van besonder gevaarlike plekke, soos ingange of plekke wat niemand die hele tyd kan dophou nie, of waar 'n mens net die minimum (of dalk selfs geen) beskerming kan dra nie? Baddens het baie sulke negatiewe kragte aangetrek, en veral die bose oog, want dit is tog waar die mooi mense bymekaar kom. Selfs die pragtige baddens as sodanig, soos dié van die ryk mense in Romeinse stede (dié in die huis van Menander, byvoorbeeld) wat sulke toonbeelde van sukses en voorspoed is, kon allerlei strale van die bose oog aantrek. 
Hier is beeldjies of prente geplaas, apotropeïese prente. Soos die - vir ons vreemde - mosaïek by die Menanderhuis se badkamer. Sulke prente, met hulle afwerende krag, is dus bewakers.

In die lig hiervan kan ons ook die rol van Priapus binne die Romeinse wêreld beter verstaan. Priapus is 'n vrugbaarheidsgod, 'n koddige figuur met 'n groteske penis. Die dier wat met sy kultus verbind word is die esel - immers, seksdrif maak jou so onnosel soos 'n esel. Juis omdat hy 'n baie falliese figuur is, is sy afbeelding dié beskerming teen subtiele magte, soos die bose oog. Priapus is die een wat sy fallus soos ' $n$ wapen gebruik om tuine en boorde teen diewe te beskerm. Sy fallus is 'n dreigement - 'n teken van mag. Romeinse huisbase, familiehoofde, leiers kon (en het, dikwels) hulle onderdane, manlik én vroulik, verkrag as 'n vorm van straf — of sommer net om te wys wie is die baas.

Maar nie alle gebruike van die fallus was so aggressief nie.

\section{SÝ LIGGAAM}

Wat is "eroties"? Die relatiwiteit van die begrip word al te maklik ontduik. Nie net verskil dit van mens tot mens nie; dieselfde mens se ervaring van die erotiese kan verander (wat ek as tiener as eroties beskou het, is maar valerig naas dit wat ek nou opwindend ervaar). Die kompleksiteit van ons tema moenie misgekyk word nie. In wat volg, moet ek noodgedwonge veralgemeen, en ek spits my toe op die mense oor wie ons inligting het om te kan praat oor hulle seksualiteit.

Taboe en seksuele gedrag word deur ' $n$ mens se kultuur bepaal. In Aristofanes se drama Bye kom die een en ander oor vaderlike plesiertjies ter sprake. Die een karakter, Filokleon, vertel hoe hy dit geniet wanneer sy dogter klein munte uit sy mond vis met haar tong. Stel jou voor dat so iets as behoorlike gedrag beskou was.

Ek het beklemtoon dat ons insig moet hê in hoe hulle oor liggaamlikheid gedink het alvorens ons hulle erotiese waardes en vooroordele kan begryp.

Ons het bittermin aanvoeling vir hoe man-gesentreer die antieke wêreld was. Vandag in die Westerse wêreld is dit die volmaakte vroueliggaam wat advertensies, rolprente, stories, prominente situasies en wat nog interessant en besienswaardig maak. Let maar op: een of ander vroulike lyfie - skraal, jonk, uitgevat of ontbloot is altyd êrens rond as iets of iemand belangrik geag word. Hierdie 
vooroordeel van ons tye is histories beskou nogal vreemd, want dit is 'n relatiewe onlangse verskynsel.

In die antieke wêreld was dit anders. Toe was die ideale liggaam die van 'n man. Nou nie enige mannelyf nie. Die ideale liggaam was dié van 'n gespierde jongman, met 'n ge-oliede bolyf en 'n trotse, meerderwaardige houding. Dit was die beelde van jongmans wat by tempels uitgestaar het na hulle bewonderaars wat hulle as uitbeeldings van gode gesien het.

Ons moet 'n bietjie in hulle gedagtewêreld delf. In die eerste eeu - en trouens tot aan die einde van die middeleeue - was mense se mensbeeld gebou op 'n een-geslag biologiese model. Dit wil sê, 'n vrou is net die gebrekkige, onvolledige voorstelling van 'n man, met dieselfde geslagsorgane, net intern, 'n soort van (dowwe) spieëlbeeld van die man se eksterne organe. Destyds was 'n vrou 'n onvoltooide man. Galenus, 'n tweede-eeuse medikus, verduidelik uitvoerig dat vroue fisiologies dieselfde is as mans, maar as gevolg van minder "warmte" (hierdie hitte verwys na een van die vier fundamentele "elemente" waarmee die werklikheid opgemaak is) het hulle geslagsorgane binnekant vasgevang gebly.

Die oortuiging was dat vroue se reproduktiewe organe verkleinde en omgedopte weergawes van mans s'n is. Mense is minder of beter geskikte weergawes van die eintlike en ware geslag, die manlike. 'n Vrou verskil nie van 'n man soos 'n sirkel van 'n driehoek verskil nie, maar soos 'n driehoek van hout anders is as 'n driehoek van brons, soos 'n mol se oë (vroue, natuurlik) verskil van ander diere se oë.

Teen hierdie agtergrond maak die sosiale opvattings van die antieke mense sin. In die eerste eeu is die status van 'n dorp of stad nie soseer bepaal deur die inwoners of die hoeveelheid inwoners nie, maar of daar 'n forum was, tempels vir die gode, 'n teater, openbare baddens en 'n gimnasium. Neem een van hierdie plekke weg en dit is nie 'n Romeinse plek nie.

Die gimnasium was 'n integrale deel van die opvoeding van seuns en die sosiale lewe van volwasse mans. Trouens, sonder 'n gimnasium kon die Romeinse man nie 'n man wees nie. Net mans het na die gimnasium gegaan en 'n goeie burger het dikwels gegaan, baie selfs daagliks. 'n Baie goeie illustrasie van hierdie faset van die Grieks-Romeinse leefwêreld sien ons by Plato wat vertel dat Sokrates daarvan gehou het om uit te hang by Taureas se gimnasium 
naby die Tempel van die Koningin van die Gode, waar die Ateense aristokrasie gesien is. Hy sê ook dat Sokrates baie maklik oorreed kon word deur 'n aantreklike jong man om na 'n ander gimnasium te gaan.

Binne die gimnasium trek die mans uit. Alle oefening word naak gedoen - net die penis word met 'n riempie vasgebind sodat daar gemaklik gehardloop kan word. Eers word die lyf met olie gesmeer - deur 'n slaaf wat by die gimnasium werk, of jou eie een wat saamkom. Dan word daar ernstig geoefen. Oefenruimtes en oefensessies word ingedeel sodat mans in ouderdomsgroepe met hulle portuur oefen.

Oefening is hardloop, stoei, spronge, diskus werp en spiesgooi en spesifieke oefeninge vir bors- en armspiere. 'n Belangrike rede vir gereelde oefening was om jou liggaam voor te berei vir oorlog want destyds, om 'n stemgeregtige te kon wees, moes jy bereid wees om jou stad te verdedig. Met ander woorde, die reg tot stem het eers gevolg nadat jy die verantwoordelikheid van diensplig aanvaar.

Na die oefensessie word stof en olie van die lyf afgeskraap, met 'n skrapertjie. 'n Man wat doelgerig in die straat stap met olyfolievlessie en skraper - dis 'n man op pad na sy gimnasium.

In antieke portrette is mans altyd bruingebrand en die vroue spierwit. Die rede hiervoor is dat mans in die son oefen, terwyl vroue binnenshuis moet bly. Bruingebrandheid was ' $n$ aanduiding van manlikheid en 'n ligte velkleur 'n aanduiding van vroulikheid. 'n Bruingebrande vrou was nie baie aantreklik nie, want sy gedra haar nie soos dit 'n ordentlike, versorgde vrou betaam nie.

Lucianus, die rondreisende professor van die tweede eeu, skryf:

"Die jong mans is bruingebrand deur die son, met manlike gesigte; hulle vertoon gees, vuur, manlikheid. Hulle gloei met uitstaande kondisionering: nie skraal of maer nie; ook nie swaar in die lyf nie, maar ge-ets met simmetrie. Hulle het alle onnodige vlees afgesweet, en wat oor is, is goed vir krag en stamina, met geen spoor van swak kwaliteit nie. Hulle onderhou hulle liggame met die grootste ywer”.

Oefen in die gimnasium is ook 'n vertoning: mans wat mekaar opweeg en plaas. Deur hierdie vertoon en beoordeling word die hele gemeenskap eintlik beïnvloed. Immers, dit is die mans wat gesag dra. 
Omdat die 'mooi lyf' destyds gemeet is as 'n manlike lyf, verstaan ons ook hoekom Romeinse buustelyfies net 'n band van lap was. 'n Mooi bors was 'n simmetriese plat bors, soos 'n jongman s'n. Net moeders met groot gesinne en godinne het duidelike borste (en ja, daar is 'n verband). Groot borste is met breë bande plat gedruk. Dit is opvallend dat selfs in die mees eksplisiete sekstonele vanuit die Romeinse wêreld die vrou gewoonlik 'n bostuk aan het. Niks anders nie, maar die bostuk is daar.

In die gimnasium het 'n man hoe en wat hy is, gemeet deur met ander mans te kompeteer, sy liggaam te vertoon, en homself meer manlik te maak. Hier het mans gepraat, gespog, en geoordeel. Die gimnasium het die manlike liggaam 'n gesprekspunt gemaak, dit vertoon, begeerlik gemaak, maar was partykeer ook 'n bron van kommer.

Manlike viriliteit was ook broos. Die elemente droogheid en warmte - wat 'n man 'n man maak - moes in stand gehou word. Van kleins af is 'n man geleer hoe om sy karakter "droog” te hou; dit wil sê, hoe om alle spore van sagtheid uit sy houding en gemoedstoestand uit te weer en weg te hou.

Die geagtes (die invloedrykes) van die dorpe en stede het mekaar onophoudelik met skerp oë dopgehou. Hoe stap 'n man? Trippel hy soos 'n vrou drafstap hy soos 'n slaaf of sluip hy soos 'n boodskapper wat ander se vuil werk doen? Die aristokratiese jongmans is van kleinsaf geleer om grootdoenerig te stap (om te swagger) terwyl ouer aristokrate met baie status weer stadig en afgemete gestap het. ' $n$ Koning en ' $n$ generaal het met lang treë geloop. Van die laer stande is verwag om met korter treë te loop. Jongmense en vroue moes met neergeslane oë loop as daar mans naby was. Statuserkenning was ' $n$ fundamentele saak in die antieke wêreld, en met jou kop, oë en hande moes te kenne gee wanneer jy in die geselskap was van jou meerderes: neergeslane oë en oop hande.

Mense het mekaar destyds ontleed tot 'n mate wat ons moeilik kan verstaan. Hulle het geluister na die ritme in 'n man se uitspraak, na die resonansie van sy stem. Was sy gebare ferm en beheersd? Waarop dui sy houding? Enigiets kon 'n aanduiding wees van behoud of verlies van selfbeheersing. Die geringste gebaartjie kon 'n leidraad wees dat die warmte van manlikheid begin faal, dat hy dalk weerloos begin raak. 
Die rede waarom die ideale manlike lyf altyd met bykans miniatuur geslagsdele uitgebeeld was, het te doen met die opvattings van beheersdheid en selfbeheersing. Die ideale lyf is die gedissiplineerde lyf, die liggaam wat totaal onder beheer was. Die fyn, sagte penis is ondubbelsinnig aanduiding van die lyf wat vry is van onwillekeurige emosies en drifte.

Na die gimnasium besoek die mans die baddens, en weer eens is dit opvallend dat selfs naaktheid óók 'n kulturele konsep is.

Die Romeine het mans en vroue toegelaat in die baddens. Die onderskeid wat tussen groepe getref was, was tussen status en nie soseer manlik en vroulik nie. Mense het by die badhuis bymekaar gekom nie net ter wille van die stoombaddens, en om die warm water en koue afspoel te geniet nie, maar ook om te gesels, sake van openbare belang te bespreek, nuus oor te dra, om in te haal wat betref die nuutste verwikkelinge in ander mense se lewens, en veral om mekaar dop te hou. Om saam met jou vriende en kennisse tyd by die baddens deur te bring, was integraal aan die lewe van daardie mense.

By die baddens was daar ook oefenruimtes waar ouer mans of diegene wat net ligte oefening nodig het, geoefen het.

So, poedelnaak, terwyl skerp oë jou houding, gebare, liggaamsdele - jou hele, ontblote ware lyf - dophou, is nuus oorgedra, gebeure van die dag ontleed, jongmense se huwelike beplan, saketransaksies afgehandel, politieke beslissinge verfyn en advies uitgedeel.

In die baddens het advies nie net via vriende gekom nie. In Pompeije se baddens byvoorbeeld, is daar 'n reeks freskos teen die mure wat allerlei seksposisies en erotiese tegnieke uitbeeld. Daar word baie gewonder oor die redes vir die illustrasies maar die tegniese detail en sigbaarheid daarvan oortuig my dat die muurpanele 'n soort seks-handboek was, 'n openbare en toeganklike visuele teksboek vir seks.

Wat van die idees oor vroue se liggame?

Mans se liggame word gedissiplineer, die ideale lyf is die beheersde lyf. As jy 'n slaaf moet slaan, moet dit met kille redelikheid gedoen word. So hard en deeglik as wat nodig is, en nie met passie of genot of woede wat uitbars nie. Meer as wat "nodig" is, dui op kinderagtigheid, onvolwassenheid, vroulikheid. 
Die ideale man beheer sy begeerte, en beheersd, op die regte plek en tyd, penetreer hy ' $n$ ander. Penetrasie is om kinders te verwek, om gesag te vertoon, om te keer dat 'n vrou se onversadigbare sekslus haar siek maak, om sy eie liggaam te kontroleer en te reguleer.

'n Vrou, volgens antieke mense, kan nie tot sulke selfdissipline in staat wees nie. Vir haar liggaam is daar gevolglik nie sulke aspirasies nie. Die begrip “ideale vroueligaam” is vir die antieke mens 'n weerspreking want net 'n man se liggaam kan ideaal wees. Immers, 'n vrou is “'n natuurlike deformiteit”, aldus die geneeshere, filosowe en wetenskaplikes van daardie tyd. 'n Vrou se lyf is van nature nat, koud, sag en passief. Sy is poreus en sponsagtig. 'n Man natuurlik, is droog, warm, hard, en aktief.

'n Vrou is soos 'n beker, 'n kleipot, 'n houer (dis presies die woord wat Paulus gebruik, 1 Tessalonisense 4:4 - die vertalers is net vriendelik oor sy tydgebondenheid) met buise wat die verskillende ruimtes en openinge van haar lyf met mekaar verbind. As jy wil weet of sy vrugbaar is, plaas iets wat skerp ruik in haar vagina. As haar asem die volgende oggend ruik, dan kan jy die gode dank want haar buise is behoorlik oop en met mekaar verbind.

Die "kanon" vir die ideale, volmaakte liggaam is die van die man. Die manlike liggaam benodig regulering, oefening, en kan beheer word. Daarom betree hy die wêreld met standvastige, onwrikbare meerderwaardigheid. Die vrouelyf, die "onderontwikkelde man" is permanent ontoereikend weens haar bloederige, sponsagtige sagtheid.

Sy mag begeerlik, mooi en selfs gesond wees, maar haar onbeheerbare liggaam moet verkieslik deur mans beheer word. Haar liggaam behoort in elk geval altyd aan 'n man; eers aan haar pa, dan aan haar man aan wie haar pa haar "gee", nadat die nodige ooreenkomste ten opsigte van geld, goedere, ensomeer, getref is. As haar man sterf, word sy deel van haar oudste seun se besittings. Of as sy nie kinders het nie, gaan sy terug na haar pa toe. As dit nie kan gebeur nie, en sy het nie 'n duidelike, ondubbelsinnige kontrak (deur mans opgestel) wat haar eiendom beskerm nie, is sy in groot moeilikheid.

Die punt is, destyds was háár liggaam nie die nastrewenswaardige nie. Wel, nie soos 'n man se liggaam was nie. Daar was nie 'n onderskeid tussen heteroseksuele en homoseksuele begeerte 
getref nie. Die grootste versoeking was die manlike liggaam. Juis omdat sý liggaam so naby, so bekend was, nie soos die vroueliggame wat so anders, so onbekend (en so onverstaanbaar) was nie, was hý altyd voor die moontlikheid van versoeking.

Die praktyke wat "teen die natuur" beskou was, was dade as gevolg van oormatigheid, buitensporige begeerte wat buite beheer geraak het - 'n "gebrek aan selfbeheersing ten opsigte van plesier", in Plato se befaamde woorde (Leges 1.636c).

Wat het mense destyds eroties gevind? Ek het probeer aanduidings gee deur iets te beskrywe van hoe liggame en liggaamlikheid beleef is. Hierdie aanduidings is net deel van die moontlike kontekste vir erotiese belewenisse destyds, maar nogtans voldoende om afleidings te kan maak oor wat "tipies", "gewoonlik" as sexy beleef is: nie naaktheid nie, maar die vertoon van perfekte, manlike selfbeheersing.

\section{HET JY MY LIEF?}

In hierdie gedeelte wil ek twee sake bespreek. Die eerste het te doen met wedersydse liefde en eensydige begeerte, en die tweede met minagting en geweld in verhoudings.

Liefde, in die twintigste eeuse Westerse wêreld, word hoofsaaklik gesien as romantiese liefde. Die argetipe vir sulke romantiese liefde is 'n jongman van twintig wat voorhuwelikse seks met 'n dertienjarige meisie het en homself dan 'n dag of wat later die ewige instuur met 'n botteltjie gif. In die loop van die gebeure uiter die fiktiewe karakter wel die vraag "maar wat is nou in 'n naam" om die grootheid van "ware" ongevraagde liefde te evokeer, en sy dramatiese optrede illustreer die oortuiging dat sy begeerte vir die meisie alle ander belange oorskry. Die meisie beantwoord natuurlik die man se liefde; trouens die hele storie draai om die punt van wedersydse liefde.

Shakespeare se tragiese liefdesverhaal mag die Westerse wêreld se idee oor tere liefde tot uitbeelding gebring het, maar die antieke wêreld het geen benul gehad van sulke individualistiese, romantiese liefde nie. Die beroemdste en bekendste verhaal in die antieke wêreld het ook 'n held en heldin. En hulle is ook lojaal, tot vervelens toe maak albei duidelik dat lojaliteit belangrik is. Vir twintig jaar sien hulle mekaar glad nie, maar terwyl Odusseus monsters uitwis, 'n spul godinne bed toe vat en ander gevare trotseer, en Penelope 'n 
onophoudelike stroom minnaars die deur wys, sê hulle nie een keer "ek is lief vir Odusseus/Penelope" of eers "ek verlang na jou" nie. Lojaliteit beteken die huishouding gaan voort, die familie word beskerm, die familienaam bly bestaan. Dit beteken nie 'n uitsluitlike verhouding gebaseer op individuele erkenning nie.

Sokrates, terwyl hy selfmoord pleeg, stuur sy huilende vrou weg sodat hy ongesteurd met sy vriende kan redeneer en afskeid neem. Skone, tere, innige liefde is nie 'n kenmerk van antieke verhoudings nie. Pragmaties, groepsgeoriënteerd en gesagsgedrewe is beter terme.

Die woorde wat mense destyds gebruik het, dui op drif en begeerte. 'n Man begeer 'n vrou, en omgekeerd, 'n vrou begeer 'n man. Hy is nie lief vir haar nie, maar is lief vir sy ideale en sy heer (sy patroon) en die groep wat sy identiteit bepaal.

Seksuele begeerte is soos 'n vuur. Dit brand jou. Dit is nie wat 'n man wil hê nie. Dit kan (en sal) jou oorval, maar dit is nie die hoogtepunt van jou bestaan nie. Die gebruik van die woord "liefde/love" in ons dae suggereer iets soos "daar is niks belangriker as om met jou te vry nie", en baie mense sê nog steeds "(romantiese) liefde maak die lewe draaglik" maar die antieke mense het gesê "liefde" - seksuele liefde - is gevaarlik. Die tipiese gevolg daarvan vernietig en verdraai al die bande van die gemeenskap en daarom moet dit met omsigtigheid benader word.

Vandag wil ons almal verlief wees. Kyk maar net advertensieveldtogte: jonk, vrolik en verlief is die onderliggende aanname van die ideale wêreld waarin ons almal alles kan koop en geniet wat die mark bied. Die antieke wêreld ril vir so 'n aanname. Verliefdheid is onwaardige gedrag. Wanneer Kupido se pyltjie jou tref en daardie besondere sensasie deur jou lyf vloei, dan moet die lyf soveel as moontlik beheersd gehou word. Die begeerte mag onoorwinbaar wees, dit het almal verstaan, maar die ideale mens hanteer hierdie ongelukige gebeurtenis met waardigheid en manlike beheersdheid.

Selfbeheersing was een van die hoogste waardes. En dit het behels om nie begeerte te begeer nie, dit het beteken 'n man is in beheer van sy vrou, sy eie liggaam, sy huishouding. Dit was 'n wêreld wat gedryf is deur die ideale van dissipline en selfbeheersing (disciplina, modestia, temperatia). 
Stoïsynse perspektiewe het, in mindere of meerdere mate, alle opgevoede mense in die vroeëre Romeinse ryk beïnvloed. Menslike rede is nie maar net ' $n$ liggie wat skyn in die donker wêreld nie. Veel meer as net nog 'n funksie (hoe wonderlik ookal) wat by menswees gevoeg kan word, het die moontlikheid van redelikheid mense se ware aard bepaal. Die rede transformeer mense en hulle waardes juis omdat dit ' $n$ mens in staat stel om die liggaam te beheer. Veral mans kan en moet hulleself beheer; hulle heerskappy oor hulle eie liggame word weerkaats deur hulle heerskappy oor die minderes van die samelewing: die armes (vir wie hulle patrone is), vroue en natuurlik die slawe. Hartstog, passie, drif verslaaf jou denke, begeerte vir 'n ander se liggaam versteur en belemmer die rede en die vryheid van denke. Die destydse mediese skrywers sien dit as 'n siektetoestand, die gevolg van te veel "vogtigheid" in die liggaam (die oorvloedige vogtigheid van vroueliggame verklaar dus hulle emosionaliteit en onbeheerbare drifte); die filosowe skryf begeerte toe aan gebrek aan dissipline en vorming; die politici sê dit veroorsaak oorloë en stryd. 'n Handeling is verkeerd en "teen die natuur" wanneer dit uitgevoer word met drif; die ideale lewensstyl is om te doen wat gedoen moet word sonder dat passie die oorhand kry (hetsy iemand doodmaak of 'n kind verwek) - so redeneer skrywers so uiteenlopend soos Diogenes Laertius, Musonius Rufus, Epiktetos, Seneka en Klemens van Aleksandrië.

Begeerte is verbind aan oorheersing en beheersing, wat my by die tweede punt van hierdie afdeling bring.

Natuurlik, wanneer ' $n$ mens tot die liefdesdaad oorgaan en vurige genot met jou liggaam ervaar, is dit omdat die gode van passie jou in besit geneem het. Dit is iets om op trots te wees, 'n gebeurtenis wat jou meer as gewoon maak, want dit het goddelike warmte (en hardheid) deur jou menslike lyfie laat vloei.

Wat die ander een gevoel het is nie ter sake nie.

Ons sien vandag wederkerigheid as die sleutel tot 'n betekenisvolle verhouding (of ten minste, sommiges van ons). Nie net "ek het jou lief” nie, maar veral, "het jy my lief?" Immers, Juliet het óók selfmoord gepleeg. Waar daar nie teruggegee word nie, praat ons van die verleier, die hoer, die uitbuiter, die selfsugtige wellustige.

Antieke skrywers raak opgewonde oor die toekoms van die huishouding en met die oog daarop moet die instelling van die 
huwelik gesteun en beskerm word. Die huwelik (en die gevolglike huweliksreg) is hoofsaaklik 'n meganisme om die erflating te beskerm (bedoelende, in die hande van die patriarge te hou).

Duisende grafstene vermeld die respek wat daar tussen mans en vroue was tydens hulle huwelike. Op sommige lees ons selfs van vriendskap. Maar woorde vir liefde en begeerte ontbreek geheel en al. Dit is duidelik dat dit vir hulle geweldig belangrik was dat die familie moet voortbestaan. Maar liefdevolle begeerte vir jou vrou? Moenie laf wees nie, reageer die tipiese Romeinse man. Sy is tog net begeerlik heel aan die begin van die huwelik. Destyds het vroue getrou as hulle veertien of vyftien jaar oud was, mans meestal in hulle laat twintigs (in aristokratiese kringe nog ouer). Dán begeer jy haar. Immers, Eros bly by uitstek in die teenwoordigheid van hubare, jong vroue. Maar Eros dwaal ook rond. Lojaliteit en uitsluitlikheid het moet nie met begeerte verwar word nie.

In die verhale van daardie wêreld kom daar net moeilikheid waar begeerte ' $n$ rol speel: die gevolge is vernedering en bespotting op die beste, maar gewoonlik lei dit tot verwoesting en verlies.

Die belewing en uitdrukking van seksualiteit in die GrieksRomeinse wêreld het gesentreer in ongelykheid. In die destydse letterkunde word hierdie ongelykheid voorgestel deur liefdesverhoudinge te teken as plundery, roofsug, oorlogvoering, vlug en agtervolging. "Elke minnaar is 'n soldaat” dig Ovidius. Die digters van die vroeë Romeinse ryk (soos Horatius en Ovidius) verwoord die oortuiging dat vrees 'n vrou begeerliker maak. Dwang (en selfs geweld) is deel van die spel.

Daar is 'n nare, maar treffende voorval wat Plutargos ('n tipe dosent en 'n tydgenoot van die Evangelieskrywers) beskryf wanneer 'n man daarop gewys word dat sy meisie nie eintlik vir hom omgee nie. Die man antwoord: "Wanneer ek na 'n restaurant gaan eet ek vis. Ek gee nie om wat die vis van my dink nie".

Ons Romeinse voorgangers het die wêreld en menslike verhoudinge eensydig en man-gesentreer beskou. Hulle het van vroue objekte gemaak (verdinglik is dalk 'n meer korrekte beskrywing). Ongelykheid - 'n meerdere wat 'n mindere bemin, 'n mindere word bemin - was deel van al hulle sosiale instellings.

Die antieke persoon sou nie eintlik gevra het wat 'n paartjie doen nie, maar eerder watter status die betrokke individue het. 
Falliese, ongelyke liefdesverhoudinge het sosiale erkenning gehad. Die een wat status en mag had kon eintlik seksueel doen met sy minderes wat hy of sy wou. 'n Verhouding tussen mense met gelyke status met dieselfde ouderdom was eerder onaanvaarbaar as eensydige of selfs gewelddadige seksdade binne 'n verhouding.

\section{“EK SMEEK JULLE, VERANDER!”}

Dit is Origines wat hierdie woorde geuiter het, en hy wou 'n aantal biskoppe oortuig om 'n unieke lewensstyl te beoefen. Vir Origines is liggaamlike dissipline nodig, nie omdat dit goed is en/of manlikheid bevorder nie. Nee, Christene deel in 'n gans ander werklikheid met "nuwe" liggame, en gelowiges moet meedoen aan die transformasie van die oue na die nuwe. Die sigbare, huidige moet al hoe meer die onsigbare, beloofde werklikheid laat deurbreek. Deur vroomheid en onthouding word die liggaamlike verander. Die liggaam se begeerte na kos en seks is deurgange vir allerlei slegte magte, die duiwels wat mens se "hart" (jou diepste wese) binnedring. Onthouding is nie net 'n manier om die liggaam te oefen nie, dit is die identiteit van die ware liggaam.

Ons is hier ver verwyderd van die tradisionele Romeinse siening van die liggaam, maar ons is nog in die Romeinse wêreld. Origines sterf in die middel van die derde eeu, maar in 'n wêreld wat besig is om onherkenbaar te verander. 'n Aanvanklik onbekende Joodse sekte het ontwikkel tot 'n invloedryke beweging. Sestig jaar na Origines se dood sou die eerste keiser homself 'n Christen noem en die radikale, aggressiewe godsdienstige beweging waarmee hy sodoende identifiseer, word 'n wêreldgodsdiens.

Van die begin af het die volgelinge van Jesus daarop aanspraak gemaak dat hulle nie soos die wêreld is nie, dat hulle anders is met ander waardes. Maar dit is eers teen die einde van ons periode wat ons kan raaksien wat gebeur het met die koms van die Christendom en hulle strewe om nie net Romeine of Grieke of Jode te wees nie. Die liggaam word nou sondig; en Godgegewe begeerte is nou die begeerte vir 'n sprituele, nie-materialistiese lewe. Enige ander begeerte is van die duiwel en sy trawante.

In die vroeë Christendom het die idee ontstaan dat die huwelik 'n sakrament is, 'n religieuse handeling met “ewige” konnotasies. Dit het ontwikkel saam met die opvatting dat seks as sodanig vuil is, en dat ons genitalieë lelik is en bedek moet word. Hierdie idees is nie Romeinse, Griekse of Joodse opvattings nie. Oor Grieks- 
Romeinse opvattings is hierbo genoeg gesê om te volstaan. Wat antieke Joodse opvattings in die verband betref, hoef daar net op gewys te word dat hulle tradisionele reg poligamie erken, dat die rabbis gereelde seks as 'n godgegewe opdrag beskou en dat volgens opvattinge in vroeë Judaïsme 'n vrou se orgasme as noodsaaklik vir konsepsie beskou is.

Die vroeë kerk het hulle Christelike identiteit nie gevind in 'n strewe na sosiale gelykheid, of in politieke bewegings nie. Vir hulle was die ontwikkeling van 'n ander opvatting oor die liggaam primêr.

Alle gemeenskappe beskou een of ander seksuele gedrag as onaanvaarbaar - die verskeidenheid en verskille tussen gemeenskappe en kulture hieroor is verbasend, maar die feit is dat elke groep een of ander seksuele aktiwiteit onaanvaarbaar vind. Maar dat seks, die seksualiteit van die liggaam as sodanig iets is wat jou skuldig maak, 'n mens tot wellus verbind en heiligheid ondergrawe, is 'n produk van die mentaliteit van die vroeë kerk.

Die proses wat tot hierdie opvattinge gelei het, het met die Nuwe Testament begin, maar die aanleiding daartoe en die denkproses is nie net deur die Nuwe Testament gedra nie. Die Nuwe Testament is veel meer divers en kompleks as wat die vroeë kerk daarvan gemaak het.

Dit is ' $n$ bekende feit dat die Nuwe Testament nie juis mense opgewonde maak oor seksualiteit nie. Die belangrike stigtersfigure van die vroeë Christendom, Johannes die Doper, Jesus van Nasaret en Paulus van Tarsus was almal ongetroud en het neergekyk op seksuele verhoudings, deels omdat hulle verwagting van die koms van God se koninkryk so sterk was (bv 1 Kor 7:29-31). Toe sy dissipels teenoor Jesus opmerk dat dit dalk beter is om nie te trou nie, sê Hy vir hulle:

"Wat julle nou sê, is nie vir almal moontlik nie, net vir dié aan wie dit gegee is. Daar is mans wat met geboorte gekastreer is, ander is deur mense gekastreer, en ander het self gekies om gekastreer te word ter wille van die koninkryk van die hemel. Wie dit kan doen, laat hy dit doen” (Matt 19:11-12, my vertaling).

Hierdie is nie die eenvoudigste teks in die Nuwe Testament nie, maar die bedoeling van die uitspraak is ondubbelsinnig: vir die koninkryk is dit beter om nie seksuele verhoudings te hê nie. Hier is geen aanmoediging om seksualiteit te geniet nie. Nee, dis 'n 
waarskuwing: seks is 'n meganisme vir die "swakkes". Trouens, daar is selfs die uitverkorenes wat die genadegawe ontvang om geheel en al vry van seks te wees.

Of kyk na Paulus:

"Dit is goed vir hulle [ongetroues en weduwees] om ongetroud te bly soos ek. Maar as hulle hulself nie kan beheer nie, moet hulle trou, want dit is beter om te trou as om verteer te word" (1 Kor 7:8-9).

Paulus is gekant teen begeerte. Begeerte saam met seks maak dat seks sondig is. Dit is waaroor 1 Korintiërs 7 handel, naamlik die beheer van begeerte (1 Kor 7:2, 5, 9, 36). Wat Paulus betref, kan dit (soms) nodig wees om seksuele omgang binne 'n huwelik te hê. Maar dan moet dit sonder hartstog en drif wees. Begeerte verteer mens, en daaroor is niks goeds te sê nie. Begeerte loop uit op afgodediens en dié weer op sedeloosheid wat lei na vernietiging (1 Kor 10:7-9). Paulus staan in die denkstroom van destyds wat begeerte (seksdrif) sien as die oorsprong van afgodediens.

Seks mag 'n plig wees (1 Kor 7:3) en dit beskerm swak Christene teen besoedeling (1 Kor 7:2) asook teen die Satan (7:5). Maar in 1 Korintiërs 7:9 stel Paulus duidelik die òf-òf: huwelike is die manier vir swak Christene wat nie andersins hulle seksbegeerte kan beheer nie. In 1 Tessalonisense 4 verduidelik Paulus selfs dat Christenmans nie met harstogtelike drif met hulle vroue moet gemeenskap hê nie, want dit is wat die heidene wat God nie ken nie, doen.

Asketisme was nie 'n onbekende verskynsel in die antieke wêreld nie. Die Vestaalse Maagde of die maagde wat priesterprofetesse was, was egter uitsonderings in hulle wêreld. Hulle status en mag het juis daarin gelê dat hulle allermins die ideaal verteenwoordig. Sulke uitsonderings het die radikale, die teenoorgestelde van die "normale" verteenwoordig en in hulle andersheid was hulle spesiaal. Juis omdat hulle die teenoorgestelde van die ideale en volmaakte uitbeeld, het hulle spesiale, uitsonderlike take ontvang.

Maar die vroeë Christene het hierin die manier gevind om 'n Christelike identiteit tot uitdrukking te bring en vir hulle was die sleutel tot 'n gelowige lewensstyl presies daardie enkele motiewe in die Christelike tradisies wat dui op 'n asketiese houding, daardie elemente wat ' $n$ mens laat dink die liggaam is 'n probleem en seks 
die donkerkant van menswees. Deur te vas, nie te slaap nie, onophoudelike gebed en onthouding van seks het hulle die vlees gekruisig, die lyf gekasty, die warm nattigheid wat spreek van begeerte letterlik gedood.

So kon 'n vrou haar liggaam droog kry; hard, soos 'n man s'n, simmetries en sonder onnodige vlees; sy kon ophou om te menstrueer, en beslis nie meer swanger word nie - immers, in sonde word mense gebore, en in vaginale pyn word Eva se straf voltrek. Sonder mentruasiepyne kan hulle mos wys dat Eva se sonde finaal oorwin is. En dit het gewerk.

Vir die Christen in die laat antieke tyd en haar/sy liggaam vasgevang tussen die Heilige Gees en Satan en die se versoekinge, was heiligheid 'n daad van afsondering. Mans en vroue moes, wanneer hulle geloof uiteindelik sterk genoeg geword het, apart leef, sonder kontak: "heilig”.

Die ideale liggaam kry weer eens 'n nuwe houding. Nie meer die kragdadige man wat fors en voor uitstap, nie die goed ontwikkelde liggaam wat vertoon word in die gimnasium of baddens nie, nie die skoon geskraapte, gestoomde en afgespoelde liggaam nie. Die volmaakte liggaam is nou een wat geboë is, bewus van sondigheid. Verkieslik lê hy of sy plat op die grond, gesig na onder en met verborge genitalieë.

Dit is die bedekte liggaam, vuil en stinkend. Nie meer die sondige baddens waar Satan hoogty vier nie, maar die mens wat "eerlik" is oor die waaheid, naamlik dat die liggaam verderflik, verderwend en tydelik is; wat "nugter" die "werklikheid" aanvaar. Die liggaam is nou "vir die Here".

Dit help ons om te verstaan hoekom die Romeine van tyd tot tyd so opgewerk geraak het oor die Christene en soms die beweging wou uitroei. Hierdie ontwikkelinge in die belangrikste Christen-groepe het die essensie van Romein-wees bevraagteken. Sommige Romeinse leiers het goed begryp dat hier 'n nuwe, radikale nieRomeinse opvatting oor manlikheid en liggaamlikheid ter sprake is en het probeer om die - vir hulle - misrabele en misleidende en gevaarlike (want die tradisionele huishouding en huwelik word daardeur bedreig) mentaliteit probeer uitroei.

Die kontras kan ons illustreer deur na 'n slagspreuk te verwys. Dit is presies dieselfde woorde, maar die twee mans wat dit aanhaal 
het totaal verskillende bedoelings: "sine cerere et libero friget venus" - sonder kos en drank bibber seks. Terentius, die Romein, gebruik dit om sy vriende aan te moedig om lekker te eet en na 'n paar doppe sensuele plesier te geniet. Hieronimus, die kerkvader, gebruik dit om sy dissipels daaraan te herinner dat vas help om die seksdrang te beheer.

Die ideale Christelike liggaam (ver van hulle om die woord "volmaak" te gebruik) was presies die teenoorgestelde van die trotse Romein wat met ferm treë stap, homself projekteer, van kleins af geleer word om voor ander te verskyn en op te tree, om voor sy gelykes te staan met die regte houding, met waardigheid, eer, status en met die regte handgebare, met hande wat uit, na buite wys, en arms wat die wêreld kan omvat, en met 'n kyk wat die wêreld verower, 'n liggaam vertoon wat begeer word.

Die heilige, in skrille kontras, is "nederig”. Nederigheid vir die vroeë Christene was baie meer as die vermyding van arrogansie. Dit was self-vernederende, fisiese onderdanigheid. Op jou knieë, of beter, plat op die grond voor die blyplekke en grafte van ander heiliges en van die martelare moes hy of sy so lank as moontlik deurbring, huilend en prewelend met selfvernederende gebede op die lippe. Die suksesvolle Romein kon uitroep: Kyk na my! Kyk hoe groot en mooi is ek! Die Christen word geleer: Moenie na die liggaam van enige mens kyk nie, selfs nie, vir soverre dit moontlik is, jou eie nie.

Die rede (redelikheid) is nie meer die geheim tot die ware liggaam nie. Nee, selfs die rede is besmet en deur vroomheid en deur onthouding moet ook die rede getugtig word tot 'n uiting van die "nuwe" skepping.

Seks is net om kinders te verwek, en dan net vir diegene wat nie sterk genoeg is nie.

Die impak van hierdie ontwikkeling op mense se idees van die ideale verhouding (wat nagestreef moet word) en hulle belewing van die erotiese was verreikend. Vir een ding, die totale onrealisme daaragter het uitgeloop op die verbysterendste skynheiligheid. Hierdie mentaliteit het skynheiligheid as't ware ingebed in Christelike identiteit, 'n erfenis waarmee ons tot vandag toe worstel.

Die verskuiwinge in die idees oor seksualiteit en liggaamlikheid in die vroeë kerk, wat vanuit ons konteks en ons insigte beskou 
net so dwaas en vertekenend was as die antieke Romeine s'n, het tot vandag toe 'n houvas op ons gedrag en waardes.

\section{SLOTWOORD}

Die Romeinse wêreld was 'n man-gesentreerde wêreld. Die mooi begeerlike lyf was die van 'n breëbors, simmetriese jongman. Erotiese belewenisse was beleef in 'n wêreld vervul met magiese kragte en bomenslike persone. Hulle waardes was verweefd met status, hiërargie, gesag en manlike voorkeure. Dieselfde mense het in die loop van drie of vier eeue hulle opvattings oor erotiese gedrag en liggaamlikheid verander, maar steeds nog nie in terme van gelykheid, wedersydse respek, inherente skoonheid en seks as 'n volle faset van alle lywe gedink nie.

Ons wêreld is vandag baie anders. Tog is veel van ons Christelike houdings en belewenisse van seksualiteit nog steeds gekoppel aan daardie beoordelings en opvattinge van die laat antieke wêreld. Die antieke Romeine het eensydig en vertekenend oor die erotiese en seksuele gedink - maar so ook die kerk van die tweede en latere eeue. Daardie idees was betekenisvol in daardie dae vir daardie mense, maar dit is kranksinnig om vandag heimlik te lewe asof party van ons nog steeds 'n middeleeuse priester, of 'n antieke Romeinse patriarg sou wees.

In die omstandighede van vandag sou ek graag wou beklemtoon dat begeerte wederkerig moet wees om sinvol beleef te word. Liefde is 'n dialoog wat ons met ons lywe voltrek.

Oor hoe óns oor ons lyflikheid moet dink wil ek twee woorde gebruik om 'n grondliggende houding teenoor liggaamlikheid aan te dui. Sarkofobies verwys na 'n houding wat inherent wantrouig of vreesagtig teenoor ' $\mathrm{n}$ mens se liggaamlikheid staan en sarkofilies is 'n houding van aanvaarding en erkenning. Die eerste benadering sê ek het 'n liggaam en die tweede beklemtoon dat ek 'n liggaam is. In die antieke wêreld het bykans almal ten slotte 'n sarkofobiese houding aanvaar.

Die vraag is nou: lewe ons as sarkofobiese of as sarkofiliese mense voor God?

As my liggaam my self is, as ek slegs deur my liggaam voor God kan lewe, dan is die antwoord eenvoudig. Dan kan, byvoorbeeld, 'n vrou se liggaam en haar liggaamlikheid nooit as minder of minderwaardig of wat ook al beskou word nie. 
Ons kan met eerlike vrymoedigheid erken dat "die drange van ons hart" nie iets daar buite, ver, dreigend of vuil is nie. Dit is juis wat 'n mens is en, in 'n baie besliste sin, al wat mens is.

Maar daarmee sê ek iets oor my waardes en wat ek geleer het deur die antieke wêreld te bestudeer.

\section{Literatuurverwysings}

Aanhalings uit en/of verwysings na antieke outeurs, min-of-meer in die volgorde soos dit in die teks voorkom:

Ovidius Metamorphoses $4.610 \mathrm{vv.}$

Aristoteles Metaphysica 10.9.1058a.29-30; Oeconomica 2.3.1343b.251344a.8; De generatione animalium 1.2.716a.5-716a.22, 2.4.738b.20-23, 2.5.741a.8-16, 4.3.768a.25-28.

Plato Charmides 153-155 ; Lysis 203-204.

Galenus De semine 2.1.

Aristoteles Metaphysica 10.1058a.29-32; Historia animalium 5.11.538a.13.

Lucianus Anacharsis 25.

Ovidius Amores 1.9; Horatius Carmina 1.23; Ovidius Amores 1.5. Vergelyk met Propertius 2.5.21-26; Tibullus 1.6.73-74 ("ek wil jou nie slaan nie, maar as die waansin (furor) my oorval, sal ek wens ek het nie hande nie"), Tibullus 1.10.53-66; Ovidius Ars amatoria 2.169-172.

Plutargos Erotikos 750d-e.

Origines: kyk Chadwick, HE (Ed. \& Trans.). 1954. Alexandrian Christianity. Philadelphia: Westminster; Von Campenhausen, H 1963. The Fathers of the Greek church. London: Adam \& Charles Black.

Seksualiteit in formatiewe Judaïsme (1e-3e eeue): Boyarin, D 1993. Carnal Israel: Reading sex in Talmudic literature. Berkeley: University of California Press. Daar is insiggewende inligting en baie goeie bespreking oor idees en houdings ten opsigte van die liggaam in Boyarin, D 1999. Dying for God: Martyrdom and the making of Christianity and Judaism. Stanford: Stanford University Press.

Mt 19.11-12: Moxnes, H 2003. Putting Jesus in his place: A radical vision of household and kingdom. Louisville: Westminster John Knox Press.

Terentius Eunuchus 4.5.6; Hieronimus Epistulae 54.9.

\section{Verdere literatuurverwysings:}

Brown, P 1988. The body and society: Men, women and sexual renunciation in early Christianity. London: Faber \& Faber.

Clarke, J R 1998. Looking at lovemaking: Constructions of sexuality in Roman art 100 B.C.-A.D. 250. Berkeley: University of California Press. 
Grovijahn, J M 1998. Theology as an irruption into embodiment: Our need for God. Theology and Sexuality 9, 28-35.

Laqueur, T W 1990. Making sex: Body and gender from the Greeks to Freud. Cambridge (M): Harvard University Press.

Lloyd, G E R 1983. Science, folklore and ideology: Studies in the life sciences in ancient Greece. Cambridge: Cambridge University Press.

Malina, B J 2001. The New Testament world: Insights from cultural anthropology (3rd ed.). Louisville: Westminster John Knox.

Moxnes, H 2003. Asceticism and Christian identity in antiquity: A dialogue with Foucault and Paul. Journal for the Study of the New Testament 26/1, 3-29.

Richlin, A 1992. The garden of Priapus: Sexuality and aggression in Roman humor [Rev ed]. New York: Oxford University Press.

Rousselle, A 1988. Porneia: On desire and the body in antiquity. Oxford: Blackwell.

Rousselle, A 1989. Personal status and sexual practice in the Roman empire, in: Feher M (Ed), Fragments for a history of the human body, part 3. New York: Zone, 301-333.

Veyne, P 1987. The Roman empire, in Veyne P (Ed.), A history of private life, vol 1: From pagan Rome to Byzantium. Cambridge, Masschusetts: Harvard University Press, Belknap, 5-234.

Winkler, J J 1990. The constraints of desire: The anthropology of sex and gender in ancient Greece. New York: Routledge. 